ISSN 1997-342X (Online), ISSN 1991-8631 (Print)

Original Paper http://ajol.info/index.php/ijbcs http:/indexmedicus.afro.who.int

\title{
Bacterial contamination of medical doctors' white coats as contributing factor to hospital acquired infections
}

\author{
Ajibola Aliu AKANBI II ${ }^{1}$, Taofeek KAREEM ${ }^{1}$, Ayodele ADEDOJA ${ }^{4 *}$, \\ Amase NYAMNGEE ${ }^{1}$, Mohammed Bashir Uthman MUHAMMED $^{3}$, \\ Kareem ABDULKAREEM ${ }^{1}$ and Razaq Funsho ATATA ${ }^{2}$
}

\author{
${ }^{I}$ Department of Medical Microbiology and Parasitology, College of Health Sciences, University of Ilorin, \\ $P M B$ 1515, Ilorin, Nigeria. \\ ${ }^{2}$ Department of Pharmaceutics and Pharmaceutical Microbiology, Faculty of \\ Pharmaceutical Sciences, Usmanu Danfodiyo University, Sokoto, Nigeria. \\ ${ }^{3}$ Department Epidemiology and Community Medicine, College of Health Sciences, \\ University, of Ilorin, PMB 1515, Ilorin, Nigeria. \\ ${ }^{4}$ Department of Medical Microbiology and Parasitology, University of Ilorin Teaching Hospital, \\ Ilorin, Nigeria. \\ *Corresponding author; E-mail: ayodeleadedoja@gmail.com;Tel: +2347037986672
}

\begin{abstract}
This study was carried out to determine the degree of contamination by bacterial agents on the white coats in hospital setting. Multistage method was used to select respondents across cadre, sex and department for the questionnaire. Cuffs, sleeve and mouths of pocket of doctors' white coats were swabbed using wet sterile swab stick. The swabs were analyzed using standard procedure for bacterial contamination. The study revealed that $77.7 \%$ of the coats were contaminated with Staphylococcus aureus (45.1\%), Staphylococcus epidermidis (26.2\%), Klebsiella pneumoniae (22.6\%), Pseudomonas aeruginosa (3.7\%) and Enterococcus faecalis $(2.4 \%)$. White coats of male resident doctors were more contaminated than that of the female resident doctors, while white coats of doctors from the Department of Surgery had the highest degree of contamination than other Departments. There was a significant difference between the age of white coats, usage, frequency of washing and number of white coats per doctor $(\mathrm{P}<0.05)$ but no significant difference between age and number of white coats possessed on the number of isolates found on the sleeve and mouth of pocket of the white coats $(\mathrm{P}>0.05)$. Conclusively, doctors' white coats were highly contaminated with pathogenic aerobic bacteria. Proper maintenance and handling practices of the white coats are precautions to be taken in order to minimize the degree of bacterial contamination and to prevent cross contamination of healthcare associated infection pathogens in hospital setting.

(C) 2017 International Formulae Group. All rights reserved.
\end{abstract}

Keywords: Medical doctors, White coats, Bacteria, Hospital, Infection, Healthcare.

\section{INTRODUCTION}

Hospital environment have been reported to be strong contributor to the rampant cases of hospital acquired infections.
Relationship between organisms found at the site of infections and the environment has been reported (Atata et al., 2010). A white coat or laboratory coat is a knee-length 
overcoat worn by professionals in the medical field or by those involved in laboratory work. Patients expect to be treated in doctors' offices, hospitals and clinics by an individual wearing white. At virtually every medical school, the first symbolic act is the "White Coat Ceremony" originated by Arnold P. Gold, MD. This is the ceremonial "cloaking" of a doctor-to-be as she or he embarks on a medical career (Gherardi et al., 2009).

A depiction of a physician in a white coat is indeed the symbol of medicine, eclipsing the black bag or the stethoscope. But amazingly, the use of white coat has been declining even in the hospital setting due to discovery of its potential in transmitting healthcare associated infection pathogens over the past two decades (Harnett, 2001; Brandt, 2003; Douse et al., 2004). The rate of declination was investigated in a study that attributed the declining usage of white coat in the hospital environment to the perception of a large proportion of doctors and that white coats transmit hospital-acquired infections (Douse et al., 2004). Although those authors did not find any studies demonstrating increased risk in this regard, several reports of bacterial contamination of white coats $(25 \%$ in one study) and nurses' uniforms suggest a potential risk (Douse et al., 2004).

White coats are known to be potentially contaminated with pathogenic bacteria and there has been always a concern about the risk of transmitting pathogenic bacteria in hospital settings (Zachary et al., 2001; Chacko et al., 2003; Burden et al., 2011; Burden et al., 2013; Robati et al., 2013). It is the interest of this study to determine the degree of contamination and the type of aerobic bacterial agents found on the white coat as well as to identify possible precautions that are to be taken in order to prevent the risk of transmitting the agents in the hospital setting.

\section{MATERIALS AND METHODS}

\section{Study area and population of interest}

This study was carried out in Ilorin among the doctors at University of Ilorin
Teaching Hospital, in Ilorin the capital of Kwara State situated in north-central part of Nigeria. The University of Ilorin Teaching Hospital is a tertiary health institution serving about millions inhabitants of Kwara State, Nigeria as well as patients from the neighbouring Niger State, Osun and Oyo State. The majority of inhabitants are civil servants, artisans and farmers. A total of 103 doctors made up of 1 consultant, 69 resident doctors and 33 house officers were recruited into this study. They were from the Department of Surgery, Medicine, Peadiatrics, and Obstetrics and Gynaecology. Seventy four (71.8\%) were males and 29 (28.2\%) females.

\section{Questionnaire design}

The questionnaire was used to determine their socio-demographic characteristics and their white coats maintenance and handling practices.

\section{Sampling technique}

Multistage method was used to select respondents for the questionnaire from University of Ilorin Teaching Hospital, Nigeria. Consultants, Resident doctors and House officers were involved in the study in the departments of Surgery, Paediatrics, Obstetrics and Gynaecology and Medicine.

\section{Sample collection for microbiological analysis}

Sterile swab stick moistened in normal saline was used to swab the desired sites on the white coats (Loh et al., 2000). The swab samples were processed according to standard microbiological procedure. The isolates were identified accordingly (Cheesbrough, 2000). Briefly the swab samples were transported to the microbiology department within one hour of collection to prevent drying of the swabs. Swabs were immediately inoculated on MacConkey agar, Chocolate agar, Blood agar and Cystine lactose electrolyte-deficient agar (CLED) and incubated at $37{ }^{\circ} \mathrm{C}$ aerobically for 24 to 48 hours. Anaerobic cultures were not done due to logistic difficulties. Bacterial colonies on the agar plates were then Gram 
stained. Bacterial isolates were subjected to biochemical tests for identification and classification.

\section{Statistical analyses}

Data collected were analyzed using SPSS version 20 statistical software. The analysis of the impact of the predictors on the isolates found on the sleeve and mouth of pocket of the respondents' white coats was done with the use of ordinal logistic regression using Statistics/Data Analysis Version 11. Categorical data were compared using chi-square $\left(\chi^{2}\right)$.

\section{RESULTS}

A total of 69 resident doctors, 33 house officers and 1 consultant took part in the study representing $66.3 \%, 31.7 \%$ and $1.2 \%$ of the total population respectively. From the chart, a sum of 80 doctors' white coat was found contaminated with the Resident doctors' white coats carrying the highest number of 52 representing $65 \%$ of the total number of white coats contaminated. The degree of contamination by sex across the cadre, 74 of which were males and 29 females representing $71.8 \%$ and $28.2 \%$ of the total population respectively are shown in Figure 2. A sum of 57 males representing $71.2 \%$ of the total population of the doctors' white coats contaminated across cadres. The degree of contamination by department, 35 of which were drawn from Surgery, 29 from Medicine, 20 from Pediatrics and 19 from Obstetrics and Gynaecology representing $34.0 \%, 28.2 \%$, $19.4 \%$ and $18.4 \%$ of the total population respectively are demonstrated in Figure 3.
Doctors from Surgery Department have their white coats highly contaminated while those from Obstetrics and Gynaecology recorded the least rate of contamination. The aerobic bacterial agent isolates is shown in Table 2 . Staphylococcus aureus (45.1\%) was the most predominant while Enterococcus faecalis $(2.4 \%)$ was the least. Analysis of contamination and age of white coat usage is shown in Table 3. Although, the $\chi^{2}$ test in table 3 signifies that there was no significant association between the ages of white coats usage and whether or not white coats would be contaminated but taking into consideration the age of usage of a particular white coat is important. $\left(\chi^{2}\right)=1.172, \mathrm{df}=3, \mathrm{P}>0.05$.

Analysis of contamination and frequency of washing of white coat usage is shown in Table 4. Bacterial contamination was found more in white coat washed once in 2-3 days $(48.8 \%)$ and least contamination in white coats washed once in 2 weeks $(1.2 \%)$. There was no significant association between the frequency of washing white coats and and bacterial contamination $(\mathrm{P}>0.05)$. The analysis of bacterial contamination and number of white coats per doctor is demonstrated in Table 5. Among the doctors having two white coats, more bacterial contamination were recorded $(43.8 \%)$, while the least contamination (11.2\%) was recorded among those doctors having one coat. There was no significant association between the number of white coats possessed and bacterial contamination $(\mathrm{P}>0.05)$.

Table 1: Sampled white coats worn by medical Doctors in a North Central Tertiary Health Care in Nigeria.

\begin{tabular}{lcc}
\hline Sampled white coats & Frequency & $\mathbf{( \% )}$ \\
\hline Not contaminated & 23 & 22.3 \\
Contaminated & 80 & 77.7 \\
Total & $\mathbf{1 0 3}$ & $\mathbf{1 0 0 . 0}$ \\
\hline
\end{tabular}


Table 2: Bacteria species isolated from the sampled white coats worn by medical Doctors in a North Central Tertiary Health Care in Nigeria.

\begin{tabular}{lcc}
\hline Bacterial agents & Number of isolates & $\mathbf{( \% )}$ \\
\hline Staphylococcus aureus & 74 & 45.1 \\
Staphylococcus epidermidis & 43 & 26.2 \\
Klesiella pneumoniae & 37 & 22.6 \\
Pseudomonas aeruginosa & 6 & 3.7 \\
Enterococcus feacalis & 4 & 2.4 \\
\hline Total & $\mathbf{1 6 4}$ & $\mathbf{1 0 0}$ \\
\hline
\end{tabular}

Table 3: Analysis of contamination and age of sampled white coat usage.

\begin{tabular}{|c|c|c|c|c|c|c|}
\hline \multirow[t]{2}{*}{ Contamination } & & \multicolumn{4}{|c|}{ Age of usage } & \multirow[t]{2}{*}{ Total } \\
\hline & & 1 year & $\begin{array}{l}\text { Between } \\
1-2 \text { years }\end{array}$ & $\begin{array}{l}\text { Between } \\
\text { 3-4 years }\end{array}$ & $>4$ years & \\
\hline \multirow[t]{2}{*}{ Not contaminated } & Count & 14 & 4 & 3 & 2 & 23 \\
\hline & $\%$ & $60.9 \%$ & $17.4 \%$ & $13.0 \%$ & $8.7 \%$ & $100.0 \%$ \\
\hline \multirow[t]{2}{*}{ Contaminated } & Count & 44 & 22 & 7 & 7 & 80 \\
\hline & $\%$ & $55.0 \%$ & $27.5 \%$ & $8.8 \%$ & $8.8 \%$ & $100.0 \%$ \\
\hline \multirow[t]{3}{*}{ Total } & Count & 58 & 26 & 10 & 9 & 103 \\
\hline & $\%$ & $56.3 \%$ & $25.2 \%$ & $9.7 \%$ & $8.7 \%$ & $100.0 \%$ \\
\hline & $\mathrm{P}>0.05)$ & & & & & \\
\hline
\end{tabular}

Ordered logistic regression test to show the impact of age of white coat usage and frequency of washing on the number of isolates found on the sleeve and mouth of pocket of the white coats is depicted in Table 6 . The choice of ordered logistic regression was informed by the fact that the variables were coded in ordered form while they are aimed at finding the impact of some variables on the dependent variables. The age of white coat usage and the number of white coats possessed have positive relationship with the isolates present on the sleeve while the frequency of washing shows a negative impact on the number of isolates present on the sleeve. In other words, the result indicate that the higher the age of white coat and the number of white coats possessed, the higher the number of isolates we are likely to find on the sleeve of the white coat. However, the higher the frequency of washing, the lower the possibility of finding isolates on the sleeve of the white coat. The overall coefficients indicates a significant relationship at 0.05 significant levels which shows that the model of the relationship is a good model and incorporate compatible variables. 
Table 4: Analysis of contamination and frequency of washing of sampled white coat usage.

\begin{tabular}{|c|c|c|c|c|c|c|}
\hline \multirow[t]{2}{*}{ Contamination } & & \multicolumn{4}{|c|}{ Frequency of washing } & \multirow[t]{2}{*}{ Total } \\
\hline & & Everyday & $\begin{array}{l}\text { Once in } \\
2-3 \text { days }\end{array}$ & $\begin{array}{l}\text { Once in 4-7 } \\
\text { days }\end{array}$ & $\begin{array}{l}\text { Once in } \\
2 \text { weeks }\end{array}$ & \\
\hline \multirow[t]{2}{*}{ Not contaminated } & Count & 0 & 12 & 11 & 0 & 23 \\
\hline & $\%$ & $0.0 \%$ & $52.2 \%$ & $47.8 \%$ & $0.0 \%$ & $100.0 \%$ \\
\hline \multirow[t]{2}{*}{ Contaminated } & Count & 5 & 39 & 35 & 1 & 80 \\
\hline & $\%$ & $6.2 \%$ & $48.8 \%$ & $43.8 \%$ & $1.2 \%$ & $100.0 \%$ \\
\hline \multirow[t]{2}{*}{ Total } & Count & 5 & 51 & 46 & 1 & 103 \\
\hline & $\begin{array}{l}\% \\
(\mathrm{P}>0.05)\end{array}$ & $4.9 \%$ & $49.5 \%$ & $44.7 \%$ & $1.0 \%$ & $100.0 \%$ \\
\hline
\end{tabular}

Table 5: Analysis of ccontamination and number of sampled white coats per doctor.

\begin{tabular}{|c|c|c|c|c|c|c|}
\hline \multirow[t]{2}{*}{ Contamination } & & \multicolumn{4}{|c|}{ Number of white coat } & \multirow[t]{2}{*}{ Total } \\
\hline & & One & Two & Three & Four & \\
\hline \multirow[t]{2}{*}{ Not contaminate } & Count & 3 & 11 & 6 & 3 & 23 \\
\hline & $\%$ within & $13.0 \%$ & $47.8 \%$ & $26.1 \%$ & $13.0 \%$ & $100.0 \%$ \\
\hline \multirow[t]{2}{*}{ Contaminated } & Count & 9 & 35 & 26 & 10 & 80 \\
\hline & $\%$ within & $11.2 \%$ & $43.8 \%$ & $32.5 \%$ & $12.5 \%$ & $100.0 \%$ \\
\hline \multirow[t]{2}{*}{ Total } & Count & 12 & 46 & 32 & 13 & 103 \\
\hline & $\begin{array}{l}\% \\
(\mathrm{P}>0.05)\end{array}$ & $11.7 \%$ & $44.7 \%$ & $31.1 \%$ & $12.6 \%$ & $100.0 \%$ \\
\hline
\end{tabular}

Ordered logistic regression test to show the impact of age of white coat usage and number of white coats possessed on the number of isolates found on the sleeve and mouth of pocket of the white coats is shown in Table 7. The study showed that the age of white coat usage and the frequency of washing white coats have positive relationship with the isolates present on the mouth of the dominant pocket while the number of white coats possessed shows a negative impact on the number of isolates present on the sleeve. In other words, the result indicates that the higher the age of white coat and frequency of washing, the higher the number of isolates we are likely to find on the mouth of the dominant pocket of the white coats. However, the higher the number of white coat possessed, the lower the possibility of finding isolates on the mouth of the dominant pocket of the white coat. The overall coefficients indicates a significant relationship at 0.05 significant levels which shows that the model of the relationship is a good model and incorporate compatible variables. 
Table 6: Ordered logistic regression test to show the impact of age of white coat usage and frequency of washing on the number of isolates found on the sleeve and mouth of pocket of the white coats.

\begin{tabular}{|c|c|c|c|c|c|c|}
\hline \multicolumn{7}{|c|}{ Robust } \\
\hline * Isolate 1 & Coef. & Std. Err. & $\mathbf{z}$ & $\mathbf{P}>|\mathbf{z}|$ & \multicolumn{2}{|c|}{ [95\% Conf. Interval] } \\
\hline Age & .2061512 & .2494756 & 0.83 & 0.409 & -.2828119 & .6951143 \\
\hline Freq* & -1.192643 & .411582 & -2.90 & 0.004 & -1.999329 & -.3859573 \\
\hline $\begin{array}{l}\text { Number of } \\
*_{\text {isolates }}\end{array}$ & .1260396 & .2327098 & 0.54 & 0.588 & -.3300633 & .5821425 \\
\hline $\begin{array}{l}\text { Ordered logisti } \\
\text { Wald chi }{ }^{2}(4) \\
\text { Prob }>\text { chi2 } \\
\text { * significant at }\end{array}$ & $\begin{array}{l}9 \\
4(\mathrm{P}<0.05) \\
(2 \text {-tailed }) * \mathrm{Is}\end{array}$ & mber of obser & ration & leeves & & \\
\hline
\end{tabular}

Table 7: Ordered logistic regression test to show the impact of age of white coat usage and number of white coats possessed on the number of isolates found on the sleeve and mouth of pocket of the white coats

\begin{tabular}{lccrclll}
\hline Isolate2 & Coef. & Std. Err. & $\mathbf{z}$ & $\mathbf{P}>|\mathbf{z}|$ & \multicolumn{2}{c}{ [95\% Conf. Interval] } \\
\hline Age & .1217488 & .2173854 & 0.56 & 0.575 & -.3043187 & .5478164 \\
Freq & .0786833 & .3033899 & 0.26 & 0.795 & -.51595 & .6733167 \\
Numb -.1885935 & .2146185 & -0.88 & 0.380 & -.6092379 & .232051 \\
\hline
\end{tabular}

Prob $>$ chi2 $=0.8624(\mathrm{P}>0.05)$

* Isolate2 isolates found on the mouth of the pockets

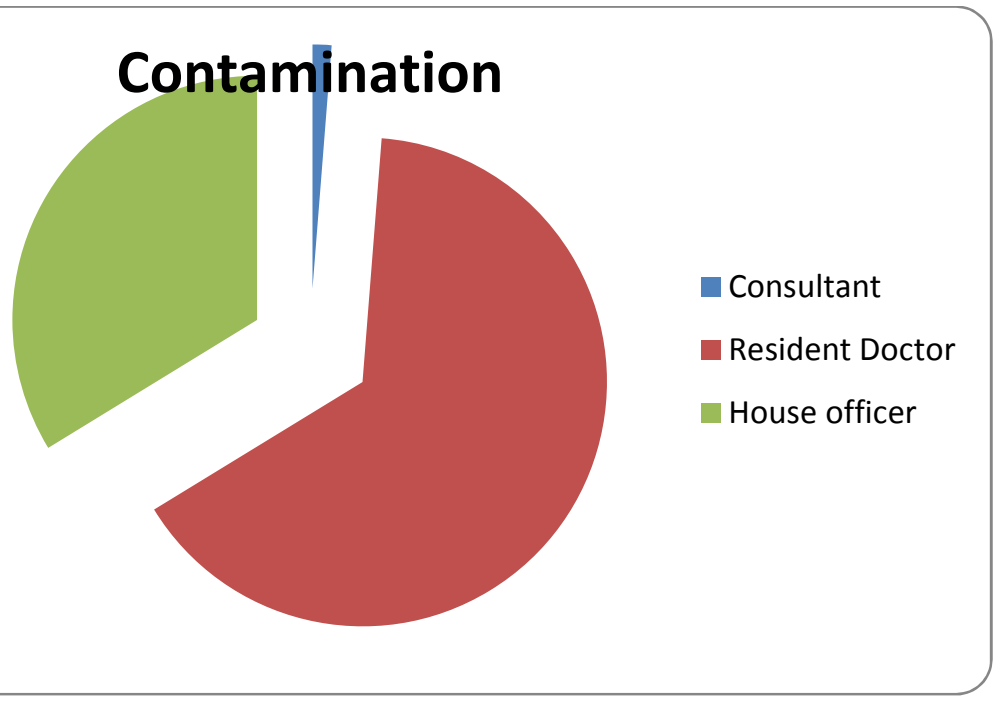

Figure 1: Degree of contamination by cadre. 


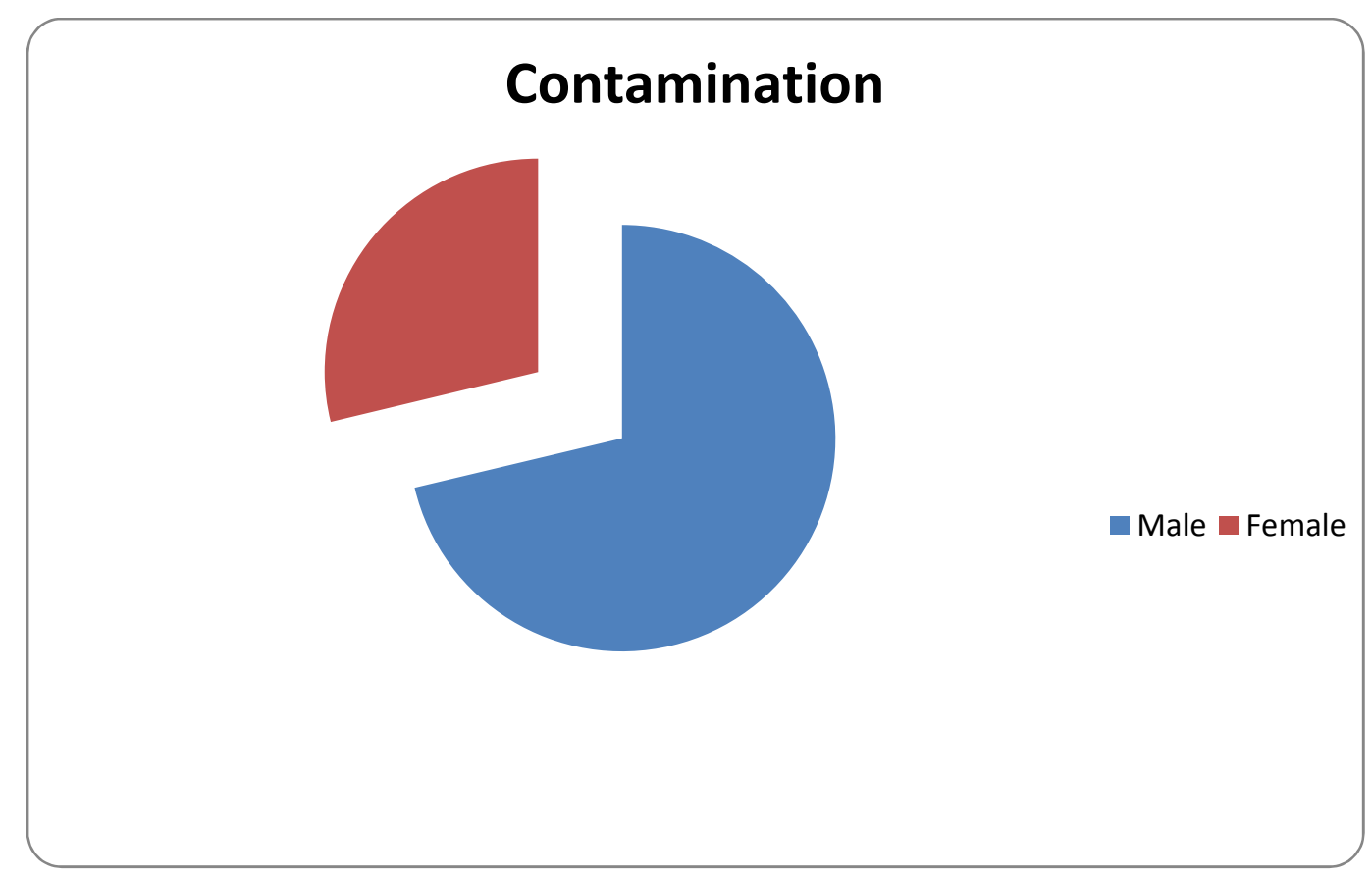

Figure 2: Degree of contamination by sex.

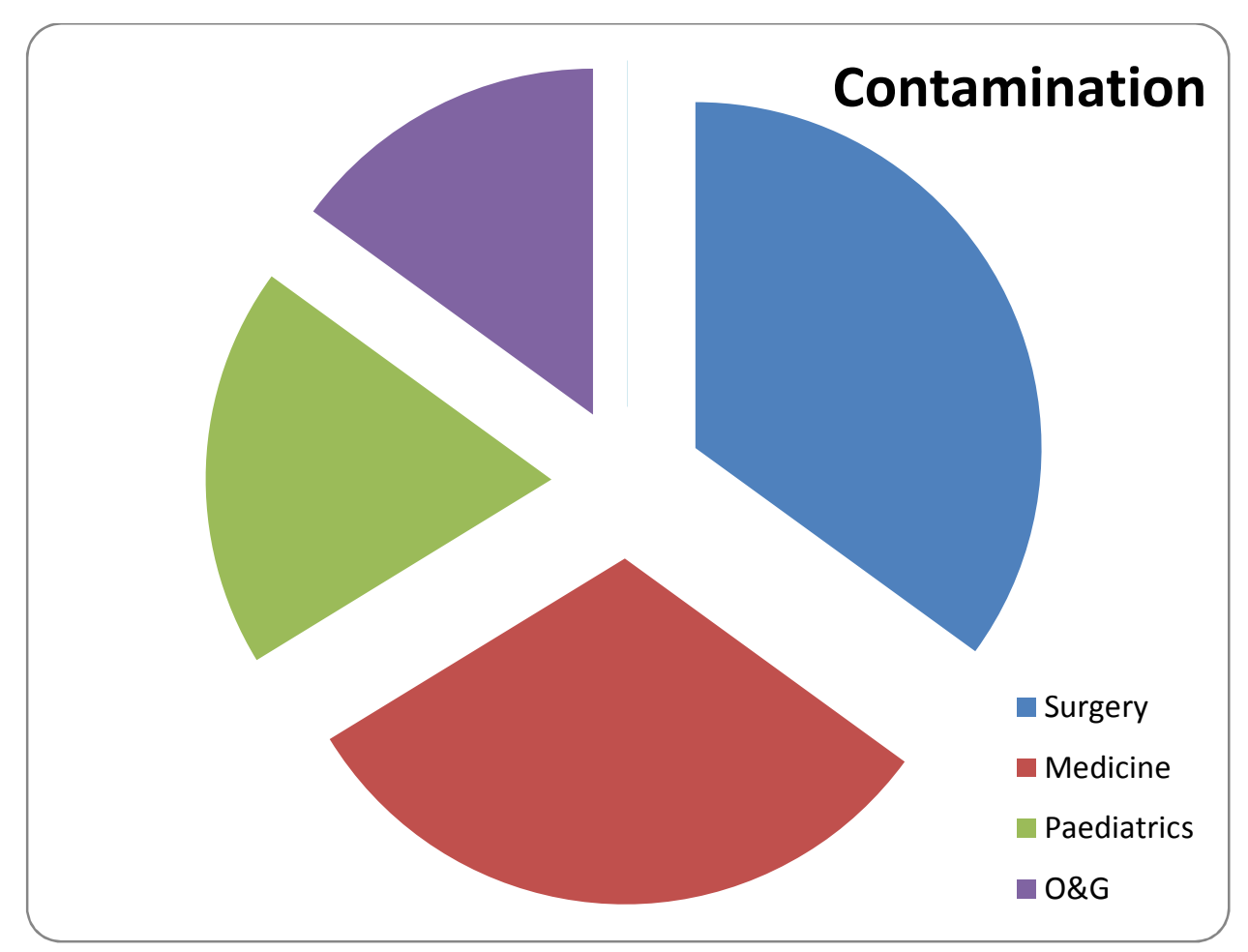

$\mathrm{O} \& \mathrm{G}=$ Obstetrics and gynecology

Figure 3: Degree of contamination by department. 


\section{DISCUSSION}

The findings of this study clearly show that white coats used by physicians can harbour high load of aerobic bacterial agents and the degree of contamination is reasonably high which agrees with the finding of other studies that showed white-coat contamination ranging from $23 \%$ to $95 \%$ (Pilonetto et al., 2004; Srinivasan et al., 2007; Treakle et al., 2009). In this study, Staphylococcus aureus was the major pathogen isolated $(28.8 \%)$ and (26.1\%) on the cuffs of the sleeve and mouth of the pocket respectively. This is in accordance with the findings of some authors (Muhadi et al., 2007; Treakle et al., 2009) but at variance with the findings of others elsewhere (Uneke and Ijeoma, 2010), in which Diphtheroids were the most common organisms isolated. Being a potential member of normal flora of human anterior nares, nasopharynx, perineal area and skin (Betty et al., 2007), which can be easily spread by the hands, expelled from the respiratory tract or transmitted by animate or inanimate objects is inevitably expected to show that degree of occurrence (Betty et al., 2007).

Consultants' white coats were found to be the least contaminated as compared to the other cadres of doctors. This agrees with the findings of some authors (Uneke and Ijeoma, 2010). The fact that consultant physicians see fewest patients compared with other categories of physicians might explain this observation. Also, the low turnout of consultants in this study could be another reason. Hierarchically, the resident doctors are the next cadre to the consultants and are expected to have contact with the patients as they are assigned with the responsibility of taking care of them while the house officers are following in the process before the consultants' intervention. Therefore, having those (resident doctors) as the highly contaminated entities is inevitable.

The white coats of the male doctors were more contaminated than their female counterparts. Though similar finding has been reported (Asima, 2012) but in contrast to the findings of others (Muhadi et al., 2007). The fact that male doctors are of the habit of keeping some of their belongings such as cell phones, pens, stethoscopes in their pockets is found to be responsible while female doctors on the other hand have alternative way of keeping all these items specifically in their hand bags and sometimes purse.

Doctors from surgery speciality have their white coats more contaminated followed by those in medicine, paediatrics and finally Obstetrics and Gynaecology. This finding contradicts what was obtained in the study elsewhere in which rate of contamination was found to be highest in paediatrics than every other speciality (Uneke and Ijeoma, 2010). In this study occurrence of Staphylococcus aureus was much more prevalent in the department of Surgery than in other departments. This finding conformed to findings of others (Betty et al., 2007) which stated that Staphylococcus aureus was less likely to be isolated from the white coat of a physician in a medical specialty than from a physician in a surgical or other specialty. Thus potential does exist for cross infection in surgical areas, particularly during examination of wounds postoperatively, although there was no evidence of such cross infection from this study.

The results of this study suggest that white-coat usage and handling practices form the basis upon which certain precautions can be made to prevent the degree of contamination among doctors and the possibility of cross contamination between doctors and their attending patients in the healthcare setting.

The percentage of contamination of white coats with age of usage less than one year is the highest as shown in Table 3 . This indicates a serious level of contradiction to other finding and not in consistent with previous work in this area (Pilonetto et al., 2004; Srinivasan et al., 2007; Treakle et al., 2009; Uneke and Ijeoma, 2010). Although, the chi-square test shows no significant relationship between the age of white coats usage and whether or not white coats would be contaminated, individual disposition to their white coats handling can be adduced as reason independent of the length of usage.

Also, the rates of contamination of those that wash their white coats every day of 
the week closely conform to other report (Uneke and Ijeoma, 2010) and slightly in consistent with previous work in this area (Pilonetto et al., 2004; Srinivasan et al., 2007; Treakle et al., 2009). The percentage of white coat contamination of those that have one white coat is ironically the least, while those with four white coats followed. This did not agree with similar studies (Uneke and Ijeoma, 2010). The utmost priority here is not on the number of white coat possessed by individual doctors but on the way they handled their coats irrespective of the number as demonstrated by the outcome of chi-square test which shows no significant relationship.

The effect of the cadre of doctors, age of white coat usage and the number of white coats possessed was assessed by ordered logistic regression in this study and were shown to have positive relationship with the isolates present on the cuffs of the sleeve while the frequency of washing shows a negative impact on the number of isolates present on the cuffs of the sleeve.

In other words, the result indicates that the higher the cadre of respondents, age of white coat and the number of white coats possessed, the higher the number of isolates we are likely to be found on the sleeve of the white coat. However, the higher the frequency of washing, the lower the possibility of finding isolates on the sleeve of the white coat. The overall coefficients indicates a significant relationship at 0.05 significant levels which shows that the model of the relationship is a good model and incorporate compatible variables. Throughout the course of the research, the investigator was unable to identify a literature that specifically assesses the impacts of cadre of respondents, age of white coat, frequency of washing and the number of white coats possessed on the number of isolates found on the sleeve of white coat. Going by this outcome, the fact that more effort is always exerted on the cuffs of sleeve while washing white coats is enough a reason for the fewer number of isolates found on the sleeve.

This study also considers the impacts of the predictor variables on number of isolates found on the mouth of the lower pockets with the test of ordered logistic regression. The result shows a negative relationship with the cadre of respondent and number of white coat possessed. Therefore, the higher the cadre and number of white coats possessed, the lower the number of isolates found on the mouth of the pocket of the white coats. The result also indicates that the number of isolates found on the mouth of the pocket of the white coat have positive relationship with the age of the white coat and the frequency of washing the white coat.

\section{Conclusion}

This study demonstrates that doctors' white coats are highly contaminated and capable of harbouring pathogenic aerobic bacteria. It also indicates that certain precautions are needed to be taken in order to reduce the degree of contamination in healthcare setting. Central to these precautions are the doctors' maintenance attitudes and handling practices towards their individual white coats coupled with having more than one white coats, constant washing of white coat after use, avoidance of using a particular white coats for a long period of time and above all embracing the use of disposable coats and removal of white coats from healthcare setting to safeguard both the doctors and their attending patients.

\section{AUTHORS' CONTRIBUTIONS}

AAAII conceived the study, supervised data collection, participated in manuscript writing. TAK collected data, perform laboratory analysis, wrote manuscript. AA, AN, NM, MBUM, KA participated in study design, data analysis, and critically revised manuscript. RFA participated in data interpretation and revision of manuscript.

\section{COMPETING INTERESTS}

The authors declare that they have no conflicts of interests.

\section{ACKNOWLEDGMENTS}

The authors are grateful to all the Doctors who participated in this study. 


\section{REFERENCES}

Asima B. 2012. White Coats as a Vehicle for Bacteria Dissemination. Journal of Clinical and Diagnostic Research, 6(8): 1381-1384.

Atata RF, Ibrahim YKE, Olurinola PF, Giwa A, Akanbi II A, 2010. Clinical bacterial isolates from hospital environment as agents of surgical wound nosocomial infections. J. Pharm \& Bio Res., 7(2): 146-155.

Betty A, Forbes D, Sahm F, Alice SW. 2007. Bailey \& Scott's Diagnostic Microbiology (12 ${ }^{\text {th }}$ Edn); 945-952.

Brandt LJ. 2003. On the value of an old dress code in the new millennium. Arch Intern Med, 163: 1277-1281.

Burden M, Cervantes L, Weed D, Keniston A, Price CS, Albert RK. 2011. Newly cleaned physician uniforms and infrequently washed white coats have similar rates of bacterial contamination after an 8 hour workday: a randomized controlled trial. $J$ Hosp Med., 6(4): 177182. DOI: $10.1002 / \mathrm{jhm} .864$.

Burden M, Keniston A, Frank MG, Brown CA, Zoucha J, Cervantes L, Weed D, Boyle K, Price C, Albert RK. 2013. Bacterial contamination of healthcare workers' uniforms: a randomized controlled trial of antimicrobial scrubs. J Hosp Med., 8(7): 380-385. Doi: 10.1002/jhm.2051.

Chacko, L, Jose S, Issac A, Bhat KG. 2003. Survival of nosocomial bacteria on hospital fabrics. Indian Journal of Medical Microbiology, 21(4): 291.

Cheesbrough M. 2000. District Laboratory Practice in Tropical Countries (Part 2). Cambridge University Press: Cambridge, UK; 243.

Douse J, Derrett-Smith E, Dheda K, Dilworth JP. 2004. Should doctors wear white coats? Postgrad Med, 80: 284-286.

Gherardi G, Cameron J, West A, Crossley M. 2009. Are we dressed to impress? A descriptive survey assessing patients' preference of doctors' attire in the hospital setting. Clinical Medicine, 9(6): 519-524.

Harnett PR. 2001. Should Doctors Wear White Coats? Med J Aust, 174: 343344.

Loh W, Ng VV, Holton J. 2000. Bacterial flora on the white coats of medical students. J Hosp Infect, 45: 65-68.

Pilonetto M, Rosa EA, Brofman PR, Baggio D, Calvário F, Schelp C. 2004. Hospital Gowns as a Vehicle for Bacterial Dissemination in an Intensive Care Unit. Braz J Infect D, 8(3): 206-210.

Robati R, Farokh MM, Jaberi FM, Hashemi SA. 2013. Effect of white coats on spread of nosocomial infection. European Journal of Experimental Biology, 3(3): 156-159.

Srinivasan M, Uma A, Vinodhkumaradithyaa A, Gomathi S, Thirumalaikolundusubramanian P. 2007. The Medical Overcoat- Is It a Transmitting Agent for Bacterial Pathogen? Japan J. Infect. D., 60: 121122.

Treakle AM, Thom KA, Furuno JP, Strauss SM, Harris AD. 2009. Bacterial Contamination of Health Care Workers' White Coats. American J Infect Cont, 37(2): 101-105.

Muhadi SA, Aznamshah NA, Jahanfar S. 2007. A cross sectional study on the microbial contamination of the medical student's white coats. Malayasian $J$ Micro, 3(1): 35-38.

Uneke CJ, Ijeoma PA. 2010. The potential for nosocomial infection transmission of the white coats which were used by physicians in Nigeria: Implications for improved patient-safety initiatives. World Health and Population, 11(3): 4454.

Zachary KC, Bayne PS, Morrison VJ, Ford DS, Silver LC, Hooper DC. 2001. Contamination of gowns, gloves, and stethoscopes with vancomycin resistant enterococci. Infection Control and Hospital Epidemiology, 22(9): 560-64. 